\begin{tabular}{|c|c|c|}
\hline$W_{\text {INESEG }}$ & $\begin{array}{l}\text { INTERNATIONAL } \\
\text { ENGINEERING, } \\
\text { SCIENCE AND } \\
\text { EDUCATION } \\
\text { GROUP }\end{array}$ & $\begin{array}{l}\text { Middle East Journal of Science } \\
\text { (2018) 4(2): } 99-103 \\
\text { Published online December 26, } 2018 \quad \text { (http://dergipark.gov.tr/mejs) } \\
\text { doi: } 10.23884 / \text { mejs.2018.4.2.05 } \\
\text { e-ISSN 2618-6136 } \\
\text { Received: December 10, 2018 Accepted: December 20, } 2018 \\
\text { Submission Type: Research Article }\end{array}$ \\
\hline
\end{tabular}

\title{
DETERMINATION OF SILAGE QUALITY CHARACTERISTICS OF FEED PEAS (Pisum sativum L.), TRITICALE AND MIXTURES GROWN IN DIYARBAKIR CONDITIONS
}

\section{Gökhan GELIR, Muzaffer DENLÏ}

Dicle University, Agricultural Faculty, Department of Animal Science, Diyarbakır,Turkey

*Corresponding author; muzaffer.denli@gmail.com

\begin{abstract}
:
This research was aimed to determine the quality characteristics of the silages obtained from the feed peas (Pisum sativumsupsp arvense L.), triticale and their mixtures cultivated in Diyarbakir provinces. In this study, experimental groups were composed of 5 groups consisting of 3 repeats, triticale and mixtures of different levels which are; 1) Feed peas, 2) Triticale, 3) Feed peas (50\%) + Triticale (50\%), 4) Feed peas $(25 \%)+$ Triticale $(75 \%)$ and 5) Feed peas $(75 \%)+$ Triticale $(25 \%)$. The samples were analyzed after 60 days of incubation in $2 \mathrm{~kg}$ plastic drums. In chemical analyzes; the highest $\mathrm{pH}$ value (4.15) was obtained from the triticale silage, while the lowest $\mathrm{pH}$ value (4.08) was obtained from the feed beetle silage $(P<0.05)$. Similarly, lactic acid concentration was the highest $(2.19 \%)$ in the silage, while the lowest level (1.96\%) was found in the feed beetle silage $(P<0.05)$. As a result; Increase of feed peas ratio in ensiled material increased the ratio of $C P, A D F, N D F$, propionic acid and acetic acid, which is a desirable feature in a quality silage, but decreased lactic acid ratio. In addition, it was determined that mixture of triticale and feed pea plants with $25 \%$ of feed peas $+75 \%$ triticale is the most ideal mixture in terms of silage quality in the areas having the ecological conditions of Diyarbakır province.
\end{abstract}

Key words: Feed peas silage, triticale silage, different mixing ratios, Diyarbakur conditions.

\section{Introduction}

Livestock in our country has a great importance in the general economy and agriculture. Our country is very suitable for animal husbandry in terms of natural resources and ecological conditions. Turkish Statistical Institute (TÜIK) reports that our livestock assets approaching 15 million heads have reached 44 million head in the first quarter of 2017 [1].

The amount and quality of the feed sources used in the ruminant nutrition which constitute the main source of meat and milk production and the ration formulation are extremely important for an economical and successful production. In animal production, feed and animal feeding costs account for approximately $70 \%$ of the total cost of the enterprises. This rate may vary according to various factors. These factors are generally the mode of production, the type of animal being raised, the size of the farm, and the condition of supply, the mode of feeding and the mechanization of the equipment. The animal 
species and the feeding characteristics of the animals may affect the share of feed supply in production costs due to the need for feed.

It is important to meet the roughage requirement of ruminant animals with the combined roughage feed mixture in the feeding of ruminant animals [2]. The majority of ruminant animals in our country are undernourished by roughage. Therefore, the regulations on feeding are very important for the production and development of cheap and qualified ratios [3].

The main source of roughage of cattle and sheep animals are pasture and pasture plants, crop production residues and fodder crops such as alfalfa, vetch, sainfoin and forage peas, and silage made from them. Silage is generally made from the fodder crops mixtures or maize plant. Triticale is a hybrid of wheat and rye that belongs to the wheat family, is a grain used in animal feed, quality roughage supply and silage production [4]. Feed peas are one of the important plant materials belonging to the leguminous family and it is similar to alfalfa silage in terms of nutrient content. Harvest times of plants are important for growing silage material in mixed form. Leguminous fodder crops are rich in protein but exhibit difficulty in ensilaging alone. Grain forage crops are good in terms of protein, although they are good in digestible carbohydrate content. For this reason, mixing of the plants belonging to these two families by mixing them in appropriate proportions will enable to obtain high quality roughage [5].

The aim of this study is to determine the quality of the silage made by the different rate of feed peas and triticale in cultivated in the ecological of conditions of Diyarbakır.

\section{Materials and Methods}

In this study, feed plants used in silages with quality characteristics were grown in the trial areas of Diyarbakır GAP International Agricultural Research and Training Center. The feed pea (GAP pink) registered by GAP International Agricultural Research and Training Center, Triticale (Karma - 2000) were used as a plant material.

Feed peas were harvested at the beginning of flowering and triticale were harvested during the flowering period and overturned in the shade. Plants that have been fading have been chopped about 2$3 \mathrm{~cm}$ in size. The harvesting process was done with a sickle and a knife. The plant materials which are ready for mixing are weighed in $2 \mathrm{~kg}$ plastic drums by weighing and mixing them in different ratios. All mixtures in the indicated proportions were stored in a dark and cool environment for 60 days. In this study, experimental groups were composed of 5 groups consisting of 3 repeats, triticale and mixtures of different levels which are1) Feed peas, 2) Triticale, 3) Feed peas (50\%) + Triticale (50\%), 4) Feed peas $(25 \%)+$ Triticale $(75 \%)$ and 5) Feed peas $(75 \%)+$ Triticale $(25 \%)$. Samples were taken from the drums under suitable conditions after 60 days fermentation period and then physical and chemical analyzes were made. The data were analyzed by using the one-way ANOVA with the General Linear Model (GLM) procedure of SPSS 16.0 (2011). Statistical significance was considered at P $<0.05$. Differences among means were evaluated using Tukey's test.

\section{Results and Discussion}

Results obtained from this study showed that in particular, feed peas $(25 \%)+$ triticale $(75 \%)$ mixture silages were found to be superior in terms of quality and fleig score compared to feed pea (50\%) + triticale $(50 \%)$ and feed pea $(75 \%)+$ triticale $(25 \%)$ mixture silages $(\mathrm{P}<0.05)$ (Table 1$)$. As seen in Table 1, the fleig score was in the range of 115.8 to $95.7 \%$, the highest fleig score was found in 115.8 
to triticale (100\%) silage and the lowest fleig score in 95.7 to $100 \%$ feed pea silage. Geren [6], Dracma, SG-304 and P-3163 corn cultivated as the second product in the study with the highest flieg score Dracma varieties of 100 points, and the lowest flieg score with 87 points reported that SG-304 varieties. Similarly, Öten et al. [7], maize, sorghum, alfalfa, sponges and their different ratio of silage in the ratio of 100 points and the scores of the fleig scores reported in their study.

Table 1. Results of Physical Analysis

\begin{tabular}{|l|l|c|l|}
\hline Groups & \multicolumn{1}{|c|}{ Color } & Fleig Point & \multicolumn{1}{c|}{ Quality } \\
\hline 1.Feed Peas $(100 \%)$ & Olive green & $95.71^{\mathrm{d}}$ & Moderate \\
\hline 2.Triticale $(100 \%)$ & Olive green & $115.84^{\mathrm{a}}$ & Satisfactory \\
\hline 3.Feed Peas $(50 \%)+$ Triticale & Brown green & $104.47^{\mathrm{c}}$ & Satisfactory \\
\hline 4.Feed Peas $(25 \%)+$ Triticale & Brown green & $110.48^{\mathrm{b}}$ & Good \\
\hline 5.Feed Peas (75\%) + Triticale & Brown green & $103.25^{\mathrm{c}}$ & Satisfactory \\
\hline
\end{tabular}

The most important method to be used in the determination of silage quality is chemical analysis. In chemical analysis; the level of organic acids such as lactic acid, acetic acid, propionic acid and butyric acid were determined after the fermentation period. Dry matter, crude ash, crude protein, acid detergent fiber (ADF), Neutral Detergent Fiber (NDF) values are given in Table 2. As a result of the research, the highest dry matter rate was found in $38.48 \%$ of $100 \%$ triticale silage and the lowest dry matter ratio was found in $27.02 \%$ and $100 \%$ feed pea silage ( $\mathrm{P}<0.05)$. Our findings were agree with the results obtained by Fayetörbay et al. [8], feed pea (Pisum arvense L.), wheat (Triticum aestvium L.) and silages in different ratios. Similarly, Güre [9] reported that the average silage dry matter rate was $25.3 \%$ in the silages prepared with different proportions of sweet millet and cowpea.

Table 2. Results of Chemical Analysis

\begin{tabular}{|l|c|c|c|c|c|}
\hline Groups & DM, \% & Ash, \% & CP, \% & ADF, \% & NDF, \% \\
\hline 1.Feed Peas(100\%) & $27.0^{\mathrm{d}}$ & 8.00 & $15.4^{\mathrm{a}}$ & $35.3^{\mathrm{a}}$ & $45.3^{\mathrm{bc}}$ \\
\hline 2.Triticale (100\%) & $38.5^{\mathrm{a}}$ & 8.08 & $9.7^{\mathrm{c}}$ & $26.3^{\mathrm{b}}$ & $44.7^{\mathrm{c}}$ \\
\hline 3.Feed Peas (50\%) + Triticale (50\%) & $32.7^{\mathrm{c}}$ & 8.03 & $11.3^{\mathrm{bc}}$ & $29.6^{\mathrm{ab}}$ & $46.4^{\mathrm{bc}}$ \\
\hline 4.Feed Peas (25\%) + Triticale (75\%) & $35.6^{\mathrm{b}}$ & 7.68 & $11.1^{\mathrm{c}}$ & $27.4^{\mathrm{b}}$ & $51.8^{\mathrm{ab}}$ \\
\hline 5.Feed Peas (75\%)+ Triticale (25\%) & $31.8^{\mathrm{c}}$ & 7.72 & $13.4^{\mathrm{ab}}$ & $28.6^{\mathrm{b}}$ & $54.0^{\mathrm{a}}$ \\
\hline P Value & 0.000 & 0.508 & 0.000 & 0.007 & 0.003 \\
\hline SEM & 1.045 & 0.088 & 0.562 & 0.984 & 1.132 \\
\hline NS & $* *$ & NS & $* *$ & $* *$ & $* *$ \\
\hline
\end{tabular}

a,b,c,d Means within a column without a common superscripts differ statistically $(\mathrm{P}<0.05)$. *: $\mathrm{P}<0.05$, **: P<0.01, SEM: Pooled standard error of mean, NS: No significant (P>0.05), DM: Dry matter, CP: Crude protein, ADF: Acid detergent fiber, NDF: Neutral Detergent Fiber.

The highest crude protein content was $15.4 \%$ from $100 \%$ forage pea silage and the lowest crude protein content was $9.72 \%$ for $100 \%$ triticale silage. The crude protein content was increased in the feed 
peas ratio in the mixture, the crude protein content is increased. The highest ADF ratio was found in $35.32 \%$ of the feed pea silage and the lowest ADF ratio was $26.30 \%$ in triticale silage $(\mathrm{P}<0.05)$. The results of this study are similar to those of Ngongoni et al. [10].

The results of the $\mathrm{pH}$ and organic acid measured in the silages samples are given in Table 3. Statistically significant difference was found between the experimental groups in terms of $\mathrm{pH}$ values ( $\mathrm{P}$ $<0.05$ ). Table 3 shows that the highest silage $\mathrm{pH}$ value was found to be $4.15 \%$ from $100 \%$ triticale silage, while the lowest silage $\mathrm{pH}$ value was obtained from $4.08 \% 100 \%$ feed pea silage. In a high quality silage, the lactic acid ratio should be above $2 \%$ [11]. As a result of the study, lactic acid ratio was found to be between $1.96 \%$ and $2.19 \%$, the highest lactic acid ratio was found from $2.19 \%$ to $100 \%$ triticale silage and the lowest lactic acid ratio was found to be $1.96 \%$ and $100 \%$ feed pea silage. In addition, the rate of butyric acid is in the range of $0.004 \%$ to $0.009 \%$, the highest butyric acid ratio is $0.009 \%$ to $75 \%$ of the feed peas $+25 \%$ triticale and $25 \%$ of the pea beetle $+75 \%$ triticale mixture and the lowest butyric acid ratio is $0.004 \%$. It was determined from $100 \%$ forage pea silage. Table 3 shows that the ratio of acetic acid was in the range of $0.3 \%$ to $0.7 \%$, the highest acetic acid content was found to be $0.7 \%$ to $100 \%$ of the feed pea silage, and the lowest acetic acid ratio was $0.3 \%$ to $100 \%$ triticale silage.

Table 3. Results of $\mathrm{pH}$ and Organic Acid Analysis

\begin{tabular}{|l|c|c|c|c|c|}
\hline Groups & pH & LA & BA & PA & AA \\
\hline 1.Feed Peas(100\%) & $4.08^{\mathrm{b}}$ & $1.96^{\mathrm{d}}$ & $0.004^{\mathrm{b}}$ & $0.1^{\mathrm{d}}$ & $0.7^{\mathrm{a}}$ \\
\hline 2.Triticale (100\%) & $4.15^{\mathrm{a}}$ & $2.19^{\mathrm{a}}$ & $0.005^{\mathrm{b}}$ & $0.4^{\mathrm{b}}$ & $0.3^{\mathrm{d}}$ \\
\hline 3.Feed Peas (50\%)+ Triticale (50\%) & $4.14^{\mathrm{a}}$ & $2.09^{\mathrm{b}}$ & $0.008^{\mathrm{a}}$ & $0.3^{\mathrm{c}}$ & $0.5^{\mathrm{c}}$ \\
\hline 4.Feed Peas (25\%)+ Triticale (75\%) & $4.14^{\mathrm{a}}$ & $2.15^{\mathrm{a}}$ & $0.009^{\mathrm{a}}$ & $0.6^{\mathrm{a}}$ & $0.4^{\mathrm{d}}$ \\
\hline 5.Feed Peas (75\%)+ Triticale (25\%) & $4.13^{\mathrm{ab}}$ & $2.01^{\mathrm{c}}$ & $0.009^{\mathrm{a}}$ & $0.7^{\mathrm{a}}$ & $0.6^{\mathrm{b}}$ \\
\hline P Value & 0.007 & 0.000 & 0.000 & 0.000 & 0.000 \\
\hline SEM & 0.008 & 0.023 & 0.000 & 0.05 & 0.37 \\
\hline ND & $* *$ & $* *$ & $* *$ & $* *$ & $* *$ \\
\hline
\end{tabular}

a,b,c,d Means within a column without a common superscripts differ statistically $(\mathrm{P}<0.05)$. *: $\mathrm{P}<0.05$, **: P<0.01, SEM: Pooled standard error of mean, NS: No significant (P>0.05), LA: Lactic acid, PA: propionic acid, BA: Butyric acid, AA: Acetic acid.

In conclusion, the increase of feed peas in the silage mixture resulted in an increase in the ratio of $\mathrm{CP}, \mathrm{ADF}, \mathrm{NDF}$, propionic acid and acetic acid, which was desired in a good quality silage, and decreased in lactic acid ratio. In addition, the fleig score was very good in all applications. Our results showed that $25 \%$ of the feed pea and $75 \%$ of the triticale mixture is an ideal mixture in terms of silage quality.

\section{Acknowledgment}

This research work was financed by Dicle University Scientific Research Projects Coordination Unit (DUBAP No: Ziraat.18.001.)

\section{References}

[1] TÜIKK. Türkiye İstatistik Kurumu Web Sayfası (www.tuik.gov.tr):2017, Erişim Tarihi:11.12.2017 
[2] Sağlamtimur, T., Tansı, V., Baytekin, H., Yem Bitkileri Yetiştirme, Çukurova Üniversitesi Ziraat Fakültesi Ders Kitabı, Adana, 1998.

[3] Kutlu, H., Gül, A., Görgülü M., “Türkiye Hayvancıllı̆ının Sorunları ve Çözüm Yolları. I. Damızlık Hayvan-Kaliteli Yem”, Yem Magazin Dergisi, 34, 40-46, 2003.

[4] Konca, Y., Alçiçek, A., Yaylak, E., "Süt Sığırcılığı İşletmelerinde Yapılan Silo Yemlerinde Silaj Kalitesinin Saptanması”, Hayvansal Üretim, 46: 6-13, 2005.

[5] Demirel, R., Saruhan, V., Baran, M. S., Andiç, N., Demirel, D.Ş., "Farklı Oranlarda Ak Üçgül (Trifolium Repens) Ve Arpa (Hordeum Vulgare L.) Karışımlarının Silolanma Özelliklerinin Belirlenmesi”, Yüzüncü Yıl Üniversitesi Tarım Bilimleri Dergisi, 20 (1), 26-31, 2010.

[6] Geren, H., "Bornova Koşullarında İkinci Ürün Olarak Yetiştirilen Farklı Mısır Çeşitlerinde Ekim Zamanlarının Silaj Özelliklerine Etkisi”, Ege Üniversitesi Ziraat Fakültesi Dergisi, 38, 47- 54, 2001.

[7] Öten, M., Kiremitçi, S., Çınar, O., "Bazı Yem Bitkileri Ve Karışımlarıyla Hazırlanan Silajların Silaj Kalitelerinin Farklı Yöntemlerle Belirlenmesi”, Anadolu Ege Tarımsal Araştırma Enstitüsü Dergisi, 26 (2), 33- 43, 2016

[8] Fayetörbay, D., Gül, Z.D., Tan, M., "Yem Bezelyesi-Buğday Ve Yem Bezelyesi-Çayır Otu Karışımlarının Silaj Değerlerinin Belirlenmesi ” IX. Türkiye Tarla Bitkileri Kongresi 12-15 Eylül 2011, Bursa.Türkiye, Vol. 3, 2011, pp. 1990-1993

[9] Güre, E. Tatlı Darı (Sorghum Bicolor (L.) Moench Var. Saccharatum) Ve Börülce (Vigna Unguiculata (L.) Walp.) Karışımlarınnın Silaj Amacıyla Kullanım Olanakları Üzerine Bir Araştırma. Yüksek lisans tezi, Ege Üniversitesi Fen Bilimleri Enstitüsü, İzmir, Türkiye, 2016

[10] Ngongoni, N.T., Mwale, M., Mapiye, C., Moyo, M.T., Hamudikuwanda, H., Titterton, M., "Inclusion Of Lablab In Maize And Sorghum Silages Improves Sheep Performance", Tropical Grasslands, 42, 188-192, 2008.

[11] Uygur, A.M. Silaj Kalitesinin Fiziksel Ve Kimyasal Yöntemlerle Belirlenmesi. 2016. https://arastirma.tarimorman.gov.tr/etae/Belgeler/EgitimBrosur/127-ciftcibro.pdf Erişim tarihi: 11.12.2017 